\title{
Poor Academic Performance of Students in Agriculture at Primary Schools in Botswana: Analysis of Causes and Ways to Improve
}

\author{
Som Pal Baliyan* \\ Botswana University of Agriculture and Natural Resources, Gaborone, Botswana \\ https://orcid.org/0000-0003-0789-883X \\ Kagiso Malebalwa \\ Botswana Open University, Gaborone, Botswana \\ https://orcid.org/0000-0003-3565-5309 \\ Keregero J B Keregero \\ National University of Lesotho, Roma, Lesotho \\ https://orcid.org/0000-0001-8344-3699 \\ Kgomotso Mabusa \\ Botswana University of Agriculture and Natural Resources, Gaborone, Botswana \\ https://orcid.org/0000-0003-3052-6700
}

\begin{abstract}
This quantitative study analysed the factors that cause poor performance and identified the possible ways to improve the performance of students in agriculture at primary schools in Botswana. Data was collected using a valid and reliable questionnaire through a survey of a randomly sampled 200 students in primary schools in Botswana. A One sample t-test determined the twenty-five causes of the poor performance of students in agriculture; the six most important causes were found to be the shortage of appropriate tools and equipment, lack of libraries and laboratories, lack of out of schools activities, poor teaching methods, lack of practical work and, students' negative attitude towards learning. Female students and students studying in schools located in urban areas perceived these causes as being more important compare to their counterparts in the rural areas. An Independent t-test determined eleven causes which showed a significant difference in performance between the male and female students as well as the students in schools located in the rural and urban areas, respectively. The six most important ways to improve the students' performance were identified as the inclusion of more practical
\end{abstract}

\footnotetext{
*Corresponding author: Som Pal Baliyan, baliyansom@gmail.com
} 
work in the syllabus, ensuring help out of the classroom, increasing practical work, providing accessible internet, providing updated textbooks and activating agricultural clubs in the schools. It is recommended that the policy makers and administrators to focus on the factors causing poor performance and the ways to improve performance while revising the existing agriculture curriculum.

Keywords: academic achievement; agricultural education; academic performance; primary schools; poor performance

\section{Introduction}

Agricultural education is essential for agricultural development as it provides an avenue for the development of knowledge and skills to the manpower for the agricultural sector. It plays an important role in developing the youth to fit into the current and future needs of the changing and challenging global environment (Hurst et al., 2015; Davis \& Jayaratne, 2015). It also plays a vital role in the development of a country, particularly in the rural areas where the majority of people depend on agriculture for their livelihood (Macatta, 2016; Talathi et al., 2014). It is crucial for a country to have substantial investment in human capital for achieving sustainable economic development. Attaining a good academic performance of students is crucial in producing skilled graduates and human capital to boost the development of the human resource. Considering the importance of agriculture in the economy, agriculture was introduced as a subject in the education system of Botswana to address the needs of the diversifying economy of the country. At present, agriculture as a subject is offered at primary, junior and senior secondary and tertiary levels of education in Botswana. At primary school level, agriculture was introduced as a compulsory subject in 2005 with the aim of acquiring knowledge and skills among the young people for the improvement of the agricultural sector.

The success of a learner is generally determined by the academic performance which is generally defined in terms of scores and grades obtained. Academic performance is the ability of a student to do something and is considered as the key factor in judging the students' success, potential and capacities. Thus, the scores and grades that a student obtains measure the degree of students' academic performance. Their poor performance in agriculture at primary school level has been a concern for the past several consecutive years in Botswana (Sibanda et al., 2016). Table 1 highlights the performance of students in agriculture and its comparison to the two other main subjects of Mathematics and English in Botswana primary schools. Performance is reported on a fivepoint grade scale of A to E, showing the levels of achievement. Grades A to C are considered credit pass grades (performance) while D to $\mathrm{E}$ are pass grades (Botswana Examination Council, [BEC], 2018).

It is evident from Table 1 that, although the performance of students in Agriculture, Mathematics and English has improved since 2012, it is far lower in Agriculture than in the other two major subjects. While there has been a gradual improvement in students' performance in Agriculture over the years, it is still 
not impressive as only $55.65 \%$ of students obtained Grades A to C. In fact, Agriculture had the highest percentage of candidates with grade D (26.38\%), grade E (11.43\%) and the lowest proportion of candidates with grade A (5.38\%).

Table 1: Performance of students (\% of Grades A-C) in Agriculture and two other major subjects in primary schools in Botswana (2012 - 2018)

\begin{tabular}{llll}
\hline & \multicolumn{3}{c}{ Performance of students } \\
\cline { 2 - 3 } Year & Agriculture & Mathematics & English \\
\hline 2012 & 24.00 & 55.10 & 61.80 \\
2013 & 39.39 & 58.43 & 61.11 \\
2014 & 42.36 & 60.48 & 61.75 \\
2015 & 47.35 & 62.88 & 63.20 \\
2016 & 54.11 & 66.40 & 65.60 \\
2017 & 55.13 & 65.94 & 66.15 \\
2018 & 55.65 & 68.71 & 67.88 \\
\end{tabular}

Source: Botswana Examination Council (BEC), 2012, 2015, 2018

This reflects students' poor performance in Agriculture in Botswana primary schools (BEC, 2018). While students have shown poor performance in the other two subjects, the trend has become consistent in agricultural education (Sibanda et al., 2016). This state-of-affairs has seen the Ministry of Education and the teachers' union trading blames, with the former blaming the teachers for their inefficiency and incompetence and the latter blaming the former for not addressing the poor morale resulting from improper teacher-student ratio, the hasty introduction of the new syllabus, inadequate resources and unfavourable working environment for teachers (Mphale \& Mhlauli, 2014).

Students' poor performance in agriculture may have consequences on the socioeconomic development of the country; it may lead to the failures in their entire Primary School Leaving Examination, which may, in turn, result in unemployment, a negative attitude towards agriculture (Baliyan \& Nenty, 2015a), an unwillingness to enroll in the subject (Baliyan \& Nenty, 2015b), attracting fewer youths to study agriculture and a negative effecting on the economy of the country (Macatta, 2016; Mphale \& Mhlauli, 2014). Thus, poor performance of students in agriculture can have implications on Botswana's long term plan to diversify its economy (Solly \& Koloi-Keaikitse, 2019) and, thus, poses a threat to the efforts of the Botswana Government to realize the objectives of its Vision 2036.

The consistent poor academic performance of the students in agriculture at primary schools has been a matter of concern among the stakeholders in Botswana. Poor academic performance of students in agricultural education at primary schools in Africa may be attributed to several factors (Bayat et al., 2014; Bush et al., 2010; Spaull, 2012). No particular study has been reported in Botswana on the analysis of the causes of students' poor academic performance in agriculture. The purpose of this study was to identify and analyse the factors 
that cause poor performance in agriculture and to identify the possible ways to improve it. The study specific objectives were to:

1. Identify the factors that cause students' poor academic performance in agriculture at primary schools;

2. Determine the gender and location differences in the factors that cause poor academic performance of students in agriculture at primary schools;

3. Identify the possible ways to improve academic performance of students in agriculture at primary schools.

The objectives of this study were achieved by answering the following research questions:

1. What are the factors that cause poor academic performance of students in agriculture at primary schools?

2. Are there any gender and location differences in the factors that cause poor academic performance of students in agriculture at primary schools?

3. What are the possible ways of improving academic performance of students in agriculture at primary schools?

The following research null hypotheses were formed to answer the research questions:

1. There are no factors causing poor academic performance of students in agriculture at primary schools.

2. There are no gender and location differences in the factors causing poor academic performance of students in agriculture at primary schools.

3. There are no ways to improve academic performance of students in agriculture at primary schools.

\section{Literature Review}

\subsection{Theoretical Framework}

Learning theories are important to understand what will affect the learning and performance of students. This study is anchored within the constructivist theory which considers that individuals play an active role in constructing their own knowledge about their experiences and circumstances (Jaiswal, 2019) as children learn by doing rather than by being told (Moll, 2020). Constructivists believe that the learners learn by constructing new ideas, based on their past knowledge. However, they also argue that every individual is unique in the way they learn and perceive things and process information differently as the learners have their own mental abilities which they use to make sense of any experience or situation. The Learners preform differently because of their different cognitive interpretation of the situation as they understand differently. In line with this theory, the suggested ways of applying constructivism in teaching and learning include the research projects, problem-solving, brainstorming, collaborative learning or group learning and discovery learning (Shuell, 2016). All these constitute a pool of methodologies to be drawn upon when learning agriculture so as to facilitate students' good performance. Since agriculture is a practical subject, it ought to be taught through hands-on practice which requires active participation of students. The learners have to be instructed and then given freedom to develop skills and knowledge on their own. Teachers should use the 
learner-centred approach to suit all the learning styles and learners' abilities. Teachers should encourage active participation during the teaching and learning process (McLead, 2018), as this theory encourages the learner-centered methods of teaching and learning and active participation. This implies that active learning escalates high order thinking and stimulates deeper learning of the subject that enables students to perform better. Since agriculture is a practical subject that requires hands-on skills together with theoretical knowledge, leanercentered approach is suitable for this study as agriculture is a practical subject where students can learn and perform better themselves when they are provided with a conducive learning environment and resources. The factors that hinder students' learning and performance are part of the environment including teaching. Therefore, the constructivist theory is found suitable for this study as agriculture is a practical subject.

\subsection{The Causes to Poor Academic Performance and Ways to Improve}

The factors which have been found to cause students' poor performance in agriculture in African schools have been identified as a poor educational environment, curriculum, physical amenities, academic facilities, teachers' lack of competence as well as teaching and learning resources (Osaikhiuwu, 2014; Bizimana \& Orodho, 2014). Other negative factors include inadequate teaching and learning material (Asamoah, 2018); poor teaching methods (Gegbe \& Koroma, 2014). failure to use instructional material, inadequate coverage of the syllabus and practical work (Ojukwu, 2015; Moyo \& Maseko, 2016), shortage of tools and equipment (Tapiwa, 2021; Waithira, 2013), lack of library and laboratories (Arshad et al., 2018; Maimela \& Monyatsi, 2016; Darko et al., 2016a; Ogweno, 2015); and lack of school libraries (Jato et al., 2014; Ayaz et al., 2017). Thus, these findings on the factors causing to poor performance are not conclusive and differ from country to country.

Osman et al. (2015) found a positive relationship between the teaching and learning resources and students' performance in schools in Kenya and recommended that sufficient instructional materials be availed to students. The availability of teaching and learning resources improves students' academic performance in students (Ogweno, 2015; Mahmood \& Gondal, 2017). Therefore, it is important that all the necessary resources and infrastructural facilities for effective teaching and learning are made available (Otekunrin et al., 2019) because they enhance better teaching and learning of agriculture (Mahmood \& Gondal, 2017). Maimela and Monyatsi (2016) reported that the factors that contributed to poor academic performance of the learners in primary school included lack of parental involvement, teaching and learning materials, infrastructure facilities, learner-teacher ratio, libraries, teachers' motivation, and learner discipline. Darko et al. (2016b) determined that practical teaching of agricultural science in high schools was greatly hindered by the non-existence or lack of funds, school gardens, educational trips, educational plots and wellequipped laboratories. They found that frequent use of the lecture method by teachers, inadequate teaching and learning materials, tools, equipment, laboratories, school farms and gardens, difficulty in planning field trips, poorly motivated teachers and a poor attitude of students towards agriculture have 
been responsible for the poor teaching and learning of agriculture. In a study on resources as determinants of students' academic performance in agriculture in secondary schools in Kenya, Ogweno (2015) found that the schools with laboratories, classrooms, farms, libraries and adequate textbooks had higher mean scores compared to schools without them.

Nyandwi (2014) identified the factors that negatively affect the performance of students in Tanzania as inadequate text books, desks and chairs, shortage of qualified teachers and laboratories. David (2014) also assessed the factors that influence the academic performance of students in secondary schools in Tanzania and found that inadequate teaching and learning materials, inadequate teaching staff and lack of libraries were the major factors. A relationship between the availability of laboratories, farming facilities and students' performance in agriculture was observed in Nigeria (Nsa et al., 2014). It suggested that students who study agriculture are motivated by teaching through active participation which involves them in hands-on practical activities.

Oitsile and Oats (2020) reported inadequate resources, inability of the learners to attempt the questions and inadequate use of effective teaching methods among the causes of primary school students' poor performance in Botswana. Boipono and Margret (2014) reported that teacher pedagogy skills, teacher training in agriculture and availability of teaching and learning materials are the major causes of poor performance of students in Agriculture in Botswana. Mphale and Mhlauli (2014) identified the contributing factors to poor performance as inadequate resources, the low morale of teachers, lack of parental involvement, lack of preparedness among teachers and students for any change, lack of incentives for teachers, lack of seriousness among students about their work, improper assessment and lack of support for homework. Kobote (2014) did not show a clear trend in the performance of students in Tanzania rural and urban schools; performance was poor in the rural schools whereas the performance of girls was poorer than that of boys in urban schools. Ezeudu et al. (2014) and, Bulala et al. (2014) did not find any significant difference in academic performance of students in urban and rural schools. Thus, these findings on the factors that cause poor performance are not conclusive and differ from country to country.

\section{Methodology}

\subsection{Research Design}

This study aimed to analyse the factors that cause poor performance and to identify the possible ways to improve the performance of students in agriculture at primary schools in Botswana. A quantitative survey and descriptive research design were adopted to achieve the aim of the study. A quantitative survey research investigates attitudes or opinions of a population by studying a sample of that population and using its responses to explore and describe the factors of influence on the population of interest (Creswell, 2017). 


\subsection{Population and Sampling}

The population of this study comprised the standard seven students in the Government primary schools in Botswana. In order to identify the differences between the performance of male and female students in schools (Kabote et al., 2014; Rahmawati \& Ummah, 2020; Mutua \& Oyoo, 2020), two schools located in the rural areas and two schools located in the urban areas were purposively selected. Thereafter, a simple random sampling method was used to select an equal number of male and female students $(n=25)$ from each of the four sampled schools. Thus, 100 students from the rural schools and 100 students from the urban schools gave a total sample of 200 students for data collection.

\subsection{Construction of Data Collection Instruments}

Based on the literature and the researcher's consultation with the agriculture teachers, a questionnaire was constructed for data collection. The questionnaire comprised three parts. The first part sought the demographic information of the students. The second part focused on 25 factors which may influence academic performance and the third part encompassed 25 items that may improve academic performance specifically in agriculture. All the items in the second and third part of the questionnaire were measured on a four-point Likert-type scale: (1) strongly disagree, (2) Disagree, (3) Agree, (4) strongly agree. The validity of the questionnaire was approved by a panel of four experts in the teaching and learning of agriculture. As a measure for ensuring the reliability of the questionnaire, Cronbach's alpha reliability coefficients were calculated to be .709 and .821 for the causes of poor performance and the ways of improving the performance, respectively. This rendered the questionnaire reliable as the coefficients were greater than the acceptable minimum level of .70 (Taber, 2018).

\subsection{Data Collection and Data Analysis}

Data was collected through a survey as this has been the method used to ascertain the perception of the stakeholders in agricultural education research (Thoron, \& Myers, 2010) and was considered as being cost effective for gathering data (Saunders et al., 2016). The questionnaire was distributed among the sampled students by the teachers of agriculture and was returned to the researcher. Data was analyzed using SPSS version 25 whereby a one sample ttest was employed to identify the factors that cause poor academic performance and to identify the possible ways of improving academic performance. An Independent $\mathrm{t}$-test was used to determine whether the gender of students and the location of schools have an impact on the academic performance of students in agriculture.

\section{Results}

\subsection{The Causes of Students' Poor Performance}

To identify the causes of students' poor performance in agriculture, the null hypothesis tested was stated as: there are no significant factors that cause poor academic performance of students in agriculture. A one sample t-test was conducted to test the hypothesis where the score of all the twenty-five causes of poor performance was considered as the test variable. The finding are presented in Table 2 which shows that the null hypothesis was rejected $(M=75.12, S D=8.53$, 
$\mathrm{t}=20.93, \mathrm{p}=.000$ ). This implies that there are causes of students' poor performance in agriculture.

Table 2: One Sample t-test Determining the Causes to Poor Performance of Students $(\mathrm{df}=199)$

$\begin{array}{llllll}\text { Causes of poor performance } & M & \text { SD } & t & M^{*} & p\end{array}$

$\begin{array}{llllll}\text { Overall causes of poor performance } & 75.12 & 8.53 & 20.93 & 12.62 & .000\end{array}$

* Mean difference (MD) is significant at $\mathrm{p}<.05$.

Further, each of the twenty-five causes of students' poor performance were also assessed individually whereby the score of each of the causes of poor performance was considered as a test variable. The findings are presented in Table 3 where the causes of students' poor performance are ranked according to their importance. All the twenty-five causes of students' poor performance were found to be significant at $\mathrm{p}<.05$. The six most significant causes of students' poor performance in agriculture were found to be the shortage of tools and equipment $(\mathrm{M}=3.29, \mathrm{SD}=.785)$, lack of libraries and laboratories $(\mathrm{M}=3.21$, $\mathrm{SD}=.841)$, lack of out-of-school activities $(\mathrm{M}=3.19, \mathrm{SD}=.853)$, poor teaching methods $(\mathrm{M}=3.18, \mathrm{SD}=.753)$, lack of practical work $(\mathrm{M}=3.15, \mathrm{SD}=.843)$ and, students' negative attitude towards learning $(\mathrm{M}=3.15, \mathrm{SD}=.825)$.

Table 3. One Sample t-test determining the causes to poor performance of students $(d f=199)$

\begin{tabular}{lllllll}
\hline Rank & Causes of poor performance & $\mathbf{M}$ & SD & $\mathbf{t}$ & $\mathbf{M D}^{*}$ & $\mathbf{p}$ \\
\hline 1 & Shortage of tools and equipment & 3.29 & .785 & 14.13 & .785 & .000 \\
2 & Lack of libraries and laboratories & 3.21 & .841 & 11.86 & .705 & .000 \\
3 & Lack of out-of-school activities & 3.19 & .853 & 11.44 & .690 & .000 \\
4 & Poor teaching methods & 3.18 & .753 & 12.67 & .675 & .000 \\
5 & Lack of practical work & 3.15 & .843 & 10.90 & .652 & .000 \\
6 & Students' negative attitude & & & & & \\
& towards learning & 3.15 & .825 & 11.14 & .650 & .000 \\
7 & Teachers' negative attitude & & & & & \\
& toward teaching & 3.27 & 2.314 & 9.29 & .620 & .050 \\
8 & Shortage of textbooks & 3.12 & .731 & 11.90 & .615 & .000 \\
9 & Poor quality teachers & 3.10 & .780 & 10.78 & .595 & .000 \\
10 & Poorly committed teachers & 3.07 & .988 & 8.09 & .565 & .000 \\
11 & Poorly motivated students & 3.06 & 1.018 & 7.71 & .555 & .001 \\
12 & Lack of internet in schools & 3.05 & .939 & 8.28 & .550 & .005 \\
13 & Poor examination structure & 2.99 & .946 & 7.34 & .490 & .000 \\
14 & Lack of tutors/help out of class & 2.98 & .961 & 7.06 & .480 & .009 \\
15 & Lack of active agricultural clubs & 2.97 & .982 & 6.77 & .470 & .000 \\
16 & Too much practical work & 2.97 & .924 & 7.19 & .241 & .000 \\
17 & Insufficient time to complete syllabus & 2.94 & .771 & 7.98 & .455 & .000 \\
18 & Poorly committed students & 2.90 & .979 & 5.70 & .395 & .000 \\
19 & Poor parental involvement & 2.89 & .765 & 7.12 & .385 & .045
\end{tabular}




$\begin{array}{lllllll}20 & \text { Lack of homework } & 2.89 & .854 & 6.29 & .381 & .000 \\ 21 & \text { Outdated textbooks } & 2.88 & .990 & 5.43 & .380 & .000 \\ 22 & \text { Too much theoretical work } & 2.81 & .817 & 5.37 & .310 & .000 \\ 23 & \text { Lack of proper school gardens } & 2.80 & .909 & 4.587 & .295 & .000 \\ 24 & \text { Improper methods of assessment } & 2.76 & .964 & 3.74 & .255 & .000 \\ 25 & \text { Poor curriculum/ syllabus } & 2.72 & 1.057 & 2.94 & .220 & .004\end{array}$

* All the Mean differences (MD) are significant at $\mathrm{p}<.05$.

\subsection{Students' Gender and Location of Schools Differences in the Causes to Poor Performance}

To determine the students' gender and location of schools' differences in the causes to poor performance of students, the null hypothesis tested was stated as: there are no significant gender and location of schools differences in the factors cause in primary school students' poor academic performance in agriculture. An Independent t-test was employed to test this hypothesis. The gender of students and location of schools were used as independent variables whereas the causes to poor performance were treated as dependent variable. The results of the Independent t-test are presented in Table 4.

Table 4: Independent t-test determining students' gender and location of school differences in causes of poor performance of students $(\mathrm{df}=198)$

\begin{tabular}{llllllll}
\hline Variables & Levels & $\mathbf{n}$ & $\mathbf{M}$ & SD & SE & $\mathbf{t}$ & $\mathbf{p}$ \\
\hline Gender & Male & 100 & 73.23 & 8.80 & .88 & & \\
& Female & 100 & 77.01 & 7.83 & .78 & -3.207 & .002 \\
Location & Rural & 100 & 73.16 & 8.59 & .86 & & \\
& Urban & 100 & 77.08 & 8.03 & .80 & -3.332 & .001 \\
& & & & & & & \\
\hline
\end{tabular}

Table 4 showed that there is a significant gender difference in the causes of poor performance of male students $(\mathrm{M}=73.23, \mathrm{SD}=8.80)$ and female students $(\mathrm{M}=77.01, \mathrm{SD}=7.83), \mathrm{t}(198)=-3.207, \mathrm{p}=.002$. A significant difference in the location of the schools in relation to the causes of students' poor performance in agriculture was found to be $(\mathrm{M}=73.16, \mathrm{SD}=8.59)$ for the rural schools and $(\mathrm{M}=77.08, \mathrm{SD}=8.03), \mathrm{t}(198)=-3.332, \mathrm{p}=.001$ for the urban schools. These findings indicate that the male and female students in the rural schools perceive the causes of poor performance differently from those in urban schools. It further indicates that female students consider these causes more important $(\mathrm{M}=77.01)$ as compare to the male students $(\mathrm{M}=73.23)$. Moreover, students studying in urban schools perceived these causes more important $(\mathrm{M}=77.08)$ as compared to the students in the rural locations $(M=73.16)$.

In order to determine the students' gender and location of school differences in each of the causes individually, an Independent t-test was run and the findings are presented in Table 5 and Table 6 , respectively. 
Table 5: Independent t-test statistics of students' gender and the causes of poor performance of students $(\mathrm{d} f=98)$

\begin{tabular}{lllllll}
\hline Causes of poor performance & \multicolumn{7}{l}{$\begin{array}{l}\text { Gender of students } \\
\text { Male }\end{array}$} & \multicolumn{3}{l}{ Female } & & \\
& $\mathbf{M}$ & SD & M & SD & $\mathbf{t}$ & p. \\
\hline Shortage of tools and equipment & 3.25 & .892 & 3.32 & .665 & -.629 & $.001^{*}$ \\
Lack of libraries and laboratories & 3.28 & .842 & 3.13 & .837 & 1.264 & .187 \\
Lack of out-of-school activities & 3.19 & .907 & 3.19 & .880 & .354 & .180 \\
Poor teaching methods & 3.13 & .761 & 3.22 & .746 & -.844 & .596 \\
Lack of practical work & 3.12 & .902 & 3.18 & .783 & -.502 & .426 \\
Students' negative attitude & & & & & & \\
towards learning & 3.13 & .928 & 3.17 & .711 & -.342 & $.007^{*}$ \\
Teachers' negative attitude & & & & & & \\
toward teaching & 2.99 & .999 & 3.25 & .880 & -1.963 & .438 \\
Shortage of textbooks & 3.09 & .805 & 3.14 & .652 & -.483 & .053 \\
Poor quality teachers & 3.09 & .818 & 3.10 & .745 & -.090 & .286 \\
Poorly committed students & 2.72 & 1.026 & 3.07 & .902 & -2.563 & $.036^{*}$ \\
Poorly motivated students & 3.04 & 1.10 & 3.07 & .935 & -.208 & .058 \\
Lack of internet in schools & 2.96 & 1.00 & 3.14 & .865 & -1.358 & .107 \\
Poor examination structure & 2.90 & .916 & 3.08 & .971 & -1.349 & .463 \\
Lack of tutors/help out of class & 2.94 & 1.043 & 3.02 & .876 & -.587 & .055 \\
Lack of active agricultural clubs & 2.81 & 1.061 & 3.13 & .872 & -2.330 & $.027^{*}$ \\
Too much practical work & 2.74 & .883 & 2.88 & .742 & -1.213 & $.002^{*}$ \\
Insufficient time to complete syllabus & 2.77 & .886 & 3.10 & .595 & -3.093 & $.000^{*}$ \\
Poorly committed teachers & 3.00 & 1.128 & 3.13 & .825 & -.930 & $.001^{*}$ \\
Poor parental involvement & 2.82 & .702 & 2.95 & .881 & -1.204 & .977 \\
Lack of homework & 2.73 & .839 & 3.03 & .846 & -2.517 & .270 \\
Outdated textbooks & 2.72 & 1.055 & 3.04 & .898 & -2.310 & $.002^{*}$ \\
Too much theoretical work & 2.89 & .994 & 3.05 & .845 & -1.276 & $.026^{*}$ \\
Lack of proper school gardens & 2.67 & .943 & 2.94 & .861 & -1.958 & $.045^{*}$ \\
Improper methods of assessment & 2.68 & 1.034 & 2.83 & .888 & -1.101 & $.021^{*}$ \\
Poor curriculum/ syllabus & 2.57 & 1.027 & 2.87 & 1.072 & -2.023 & .700 \\
& & & & & & \\
\hline
\end{tabular}

Table 5 reflected that eleven causes show significant differences between male and female students. These causes include the shortage of tools and equipment: male students $(\mathrm{M}=3.25, \mathrm{SD}=.892)$ and Female students $(\mathrm{M}=3.32, \mathrm{SD}=.665), \mathrm{t}(98)=$ -.629, p. $=001$; students' negative attitude towards learning: male students: $(\mathrm{M}=3.13, \mathrm{SD}=.928)$ and female students $(\mathrm{M}=3.17, \mathrm{SD}=.711), \mathrm{t}(98)=-.342, \mathrm{p}=.007$; poorly committed students: male students $(\mathrm{M}=2.72, \mathrm{SD}=1.026)$ and female students $(\mathrm{M}=3.07, \mathrm{SD}=.902), \mathrm{t}(98)=-2.563, \mathrm{p}=.036$; lack of active agricultural clubs: male students $(\mathrm{M}=2.81, \mathrm{SD}=1.061)$ and female students $(\mathrm{M}=3.13, \mathrm{SD}=.872$, $\mathrm{t}(98)=-2.330, \mathrm{p}=.027$; too much practical work: male students $(\mathrm{M}=2.89, \mathrm{SD}=.994)$ and female students $(\mathrm{M}=3.05, \mathrm{SD}=.845), \mathrm{t}(98)=-1.276, \mathrm{p}=.026$; less time to complete the syllabus: male students $(\mathrm{M}=2.77, \mathrm{SD}=.886)$ and female students $(\mathrm{M}=3.10, \mathrm{SD}=.595), \mathrm{t}(98)=-3.093, \mathrm{p}=.000$; poorly committed teachers: male students $(\mathrm{M}=3.00, \mathrm{SD}=1.128)$ and female students $(\mathrm{M}=3.13, \mathrm{SD}=.825), \mathrm{t}(98)=$ $.930, \mathrm{p}=.001$; outdated textbooks: Male students $(\mathrm{M}=2.72, \mathrm{SD}=1.055)$ and female students $(\mathrm{M}=3.04, \mathrm{SD}=.898), \mathrm{t}(98)=-2.310, \mathrm{p}=.002$; too much theoretical work: male students $(\mathrm{M}=2.74, \mathrm{SD}=.883)$ and female students $(\mathrm{M}=2.88, \mathrm{SD}=.742), \mathrm{t}(98)=$ 
1.213, $\mathrm{p}=.002$; lack of proper school gardens: male students $(\mathrm{M}=2.67, \mathrm{SD}=.943)$ and female students $(\mathrm{M}=2.94, \mathrm{SD}=.861), \mathrm{t}(98)=-1.958, \mathrm{p}=.045$; and improper methods of assessment: male students $(\mathrm{M}=2.68, \mathrm{SD}=1.034)$ and female students $(\mathrm{M}=2.83, \mathrm{SD}=.888), \mathrm{t}(98)=-1.101, \mathrm{p}=.021$. The results reflect that the perception of the seven causes of the students' poor performance differs according to whether the student is male or female.

Table 6: Independent t-test statistics of location of school and causes to poor performance of students $(\mathrm{df}=98)$

\begin{tabular}{|c|c|c|c|c|c|c|}
\hline \multirow[t]{3}{*}{ Causes to poor performance } & \multicolumn{6}{|c|}{ Location of school } \\
\hline & \multicolumn{2}{|c|}{ Rural } & \multicolumn{4}{|l|}{ Urban } \\
\hline & $\mathbf{M}$ & SD & $\mathbf{M}$ & SD & $\mathbf{t}$ & $\mathbf{p}$ \\
\hline Shortage of tools and equipment & 3.28 & .817 & 3.29 & .756 & -.090 & .507 \\
\hline Lack of libraries and laboratories & 3.06 & .962 & 3.35 & .672 & -2.471 & $.035^{*}$ \\
\hline Lack of out-of-school activities & 2.97 & .948 & 3.41 & .683 & -3.767 & .147 \\
\hline Poor teaching methods & 3.07 & .856 & 3.28 & .621 & -1.986 & .273 \\
\hline Lack of practical work & 3.16 & .950 & 3.14 & .725 & .167 & $.027^{*}$ \\
\hline $\begin{array}{l}\text { Students' negative attitude } \\
\text { towards learning }\end{array}$ & 3.09 & .889 & 3.21 & .756 & -1.028 & .466 \\
\hline Teachers' negative attitude & & & & & & \\
\hline toward teaching & 3.01 & 1.087 & 3.23 & .763 & -1.656 & $.000^{*}$ \\
\hline Shortage of textbooks & 3.01 & .785 & 3.22 & .660 & -2.047 & .826 \\
\hline Poor quality teachers & 3.11 & .815 & 3.08 & .748 & .271 & .227 \\
\hline Poorly committed students & 2.87 & 1.022 & 2.92 & .939 & -.360 & .177 \\
\hline Poorly motivated students & 3.01 & 1.040 & 3.10 & 1.00 & -.624 & .700 \\
\hline Lack of internet in schools & 2.91 & 1.093 & 3.19 & .734 & -2.127 & $.000^{*}$ \\
\hline Poor examination structure & 2.88 & 1.028 & 3.10 & .847 & -1.652 & $.007^{*}$ \\
\hline Lack of tutors/help out of class & 2.93 & 1.037 & 3.03 & .881 & -.735 & $.002^{*}$ \\
\hline Lack of active agricultural clubs & 2.92 & .992 & 3.02 & .974 & -.719 & .700 \\
\hline Too much practical work & 2.93 & .956 & 3.01 & .893 & -.611 & .096 \\
\hline Insufficient time to complete syllabus & 2.90 & .798 & 2.97 & .745 & -.641 & .299 \\
\hline Poorly committed teachers & 2.98 & 1.025 & 3.15 & .947 & -1.218 & .402 \\
\hline Poor parental involvement & 2.75 & .821 & 3.02 & .681 & -2.530 & $.003^{*}$ \\
\hline Lack of homework & 2.74 & .928 & 3.02 & .752 & -2.345 & $.001^{*}$ \\
\hline Outdated textbooks & 2.83 & 1.045 & 2.93 & .935 & -.713 & $.034^{*}$ \\
\hline Too much theoretical work & 2.84 & .896 & 2.78 & .733 & .518 & .054 \\
\hline Lack of proper school gardens & 2.69 & 1.012 & 2.90 & .785 & -1.640 & $.000^{*}$ \\
\hline Improper methods of assessment & 2.69 & .971 & 2.82 & .957 & -.953 & .890 \\
\hline Poor curriculum/syllabus & 2.53 & 1.141 & 2.91 & .933 & -2.578 & $.000^{*}$ \\
\hline
\end{tabular}

Table 6 presents the eleven causes with significant difference between the rural and urban schools in the students' poor performance. These causes were: lack of libraries and laboratories: students in the rural schools $(\mathrm{M}=3.06, \mathrm{SD}=.962)$ and urban schools $(\mathrm{M}=3.35, \mathrm{SD}=.672), \mathrm{t}(98)=-2.471, \mathrm{p}=.035$; lack of practical work: students in the rural schools $(\mathrm{M}=3.16, \mathrm{SD}=.950)$ and urban schools $(\mathrm{M}=3.14$, $\mathrm{SD}=.725), \mathrm{t}(98)=.167, \mathrm{p}=.027$; teachers' negative attitude towards teaching: students in rural schools $(\mathrm{M}=3.01, \mathrm{SD}=1.087)$ and urban schools $(\mathrm{M}=3.23$, $\mathrm{SD}=.763), \mathrm{t}(98)=-1.656, \mathrm{p}=.000$; lack of internet in schools: students in rural schools $(\mathrm{M}=2.91, \mathrm{SD}=1.093)$ and urban schools $(\mathrm{M}=3.19, \mathrm{SD}=.734), \mathrm{t}(98)=-2.127$, 
$\mathrm{p}=.000$; poor examination structure: students in rural schools $(\mathrm{M}=2.88, \mathrm{SD}=1.028)$ and urban schools $(\mathrm{M}=3.10, \mathrm{SD}=.847), \mathrm{t}(98)=-1.652, \mathrm{p}=.007$; lack of tutors $/$ help out of class: students in rural schools $(\mathrm{M}=2.93, \mathrm{SD}=1.037)$ and urban schools $(\mathrm{M}=3.03, \mathrm{SD}=.881), \mathrm{t}(98)=-.735, \mathrm{p}=.002$; poor parental involvement: students in rural schools $(\mathrm{M}=2.75, \mathrm{SD}=.821)$ and urban schools $(\mathrm{M}=3.02, \mathrm{SD}=.681, \mathrm{t}(98)=$ 2.530, $\mathrm{p}=.003$; lack of home work: students in rural schools $(\mathrm{M}=2.74, \mathrm{SD}=.928)$ and urban schools $(\mathrm{M}=3.02, \mathrm{SD}=.752), \mathrm{t}(98)=-2.345, \mathrm{p}=.001$; outdated textbooks: students in rural schools $(\mathrm{M}=2.83, \mathrm{SD}=1.045)$ and urban schools $(\mathrm{M}=2.93$ $\mathrm{SD}=.935), \mathrm{t}(98)=-.713, \mathrm{p}=.034$; lack of proper school gardens: students in rural schools $(\mathrm{M}=2.69, \mathrm{SD}=1.012)$ and urban schools $(\mathrm{M}=2.90, \mathrm{SD}=.785), \mathrm{t}(98)=-1.640$, $\mathrm{p}=.000$; poor curriculum/syllabus: students in rural schools $(\mathrm{M}=2.53, \mathrm{SD}=1.141)$ and urban schools $(\mathrm{M}=2.91, \mathrm{SD}=.933), \mathrm{t}(98)=-2.578, \mathrm{p}=.000$. These results reflect the differences between the rural and urban student's perception of the seven causes of students' poor performance.

\subsection{Ways to Improve Academic Performance of Students}

The possible ways to improve academic performance of students were identified by testing the null hypothesis: there are no significant ways to improve the academic performance of the primary school students in agriculture. A one sample t-test was conducted to test the hypothesis with the overall score of all the twenty five ways to improve the students' performance were considered as a test variable. The findings are presented in Table 7 and the null hypothesis was rejected $(\mathrm{M}=78.93, \mathrm{SD}=8.95, \mathrm{t}=25.95, \mathrm{p}=.000)$, implying that there are significant ways to improve the performance of students in agriculture.

Table 7: One Sample t-test of overall possible ways to improve academic performance of students $(\mathrm{df}=\mathbf{1 9 9})$

\begin{tabular}{llllll}
\hline Variable & M & SD & $\mathbf{t}$ & MD* $^{*}$ & $\mathbf{p}$ \\
\hline Ways to improve performance & 78.93 & 8.95 & 25.95 & 16.43 & .000
\end{tabular}

* Mean difference (MD) is significant at $\mathrm{p}<.05$.

Further, a one sample t-test was employed to assess each of the ways to improve students' performance, with the score of each of the ways considered as a test variable. The findings are presented in Table 8 where the ways to improve the students' performance are ranked according to their importance. All the twenty five ways to improve students' performance were found significant at $<.05$ level of significance. Table 8 showed that the six most important ways to improve students' performance were suggested as: including more practical work in the syllabus $(\mathrm{M}=3.47, \mathrm{SD}=.633)$, ensuring tutoring/help out of class $(\mathrm{M}=3.45$, $\mathrm{SD}=.735)$, increasing practical work $(\mathrm{M}=3.35, \mathrm{SD}=.889)$, providing accessible internet $(\mathrm{M}=3.34, \mathrm{SD}=.748)$, providing updated textbooks $(\mathrm{M}=3.29, \mathrm{SD}=.719)$ and activating agricultural clubs $(\mathrm{M}=3.27, \mathrm{SD}=.779)$. 
Table 8: One Sample t-test of the possible ways to improve performance of students $(\mathrm{df}=199)$

\begin{tabular}{llllll}
\hline Rank & Ways to improve performance & $\mathbf{M}$ & $\mathbf{S D}$ & $\mathbf{t}$ & $\mathbf{M D}^{*}$ \\
\hline 1 & Including more practical in syllabus & 3.47 & .633 & 21.56 & .965 \\
2 & Ensuring tutoring/help out of class & 3.45 & .735 & 18.19 & .945 \\
3 & Increasing practical work & 3.35 & .889 & 13.45 & .845 \\
4 & Providing accessible internet & 3.34 & .748 & 15.99 & .844 \\
5 & Providing updated textbooks & 3.29 & .719 & 15.45 & .785 \\
6 & Activating agricultural clubs & 3.27 & .779 & 14.25 & .783 \\
7 & Adopting effective methods of assessment & 3.25 & .932 & 11.30 & .745 \\
8 & Improving commitment among students & 3.24 & .745 & 14.04 & .740 \\
9 & Increasing time to complete content & 3.24 & .845 & 12.31 & .735 \\
10 & Providing sufficient textbooks & 3.22 & .885 & 11.43 & .715 \\
11 & Applying effective teaching practices & 3.19 & .910 & 10.72 & .690 \\
12 & Improving out-of-school activities & 3.19 & .766 & 12.74 & .690 \\
13 & Mitigating students' negative attitude & 3.19 & .865 & 11.28 & .690 \\
14 & Improving quality of teachers & 3.18 & .948 & 10.07 & .675 \\
15 & Mitigating teachers' negative attitude & 3.10 & .845 & 10.04 & .600 \\
16 & Improving examination structure & 3.10 & .741 & 11.36 & .595 \\
17 & Motivating students and teachers & 3.08 & .882 & 9.30 & .580 \\
18 & Improving libraries and laboratories & 3.08 & .753 & 10.90 & .580 \\
19 & Providing adequate homework & 3.05 & .841 & 9.17 & .545 \\
20 & Improving commitment among teachers & 3.05 & .887 & 8.69 & .545 \\
21 & Improving school gardens & 2.99 & .792 & 8.66 & .485 \\
22 & Providing sufficient tools and equipment & 2.94 & .897 & 6.86 & .435 \\
23 & Updating curriculum/syllabus & 2.91 & .840 & 6.90 & .410 \\
24 & Reducing theoretical work & 2.91 & .793 & 7.22 & .405 \\
25 & Increasing parental involvement. & 2.90 & .827 & 6.84 & .400 \\
& & & & & \\
\hline
\end{tabular}

* Mean Differences (MD) are significant at $\mathrm{p}<.05$.

\section{Discussion}

The study determined that there are causes of poor performance of the primary school students in agriculture in Botswana. The five most serious causes are the shortage of tools and equipment, lack of libraries and laboratories, lack of out-ofschool agricultural activities, poor teaching methods and lack of practical work. Shortage of tools and equipment was the most important cause of poor performance of students in agriculture, a finding supported by Waithira (2013) and Kabugi (2013) and Muchena (2013) who contested that agriculture involves a different type of tools and should be availed for the effective teaching and learning of agriculture.

Lack of libraries and laboratories was identified as the second most important cause of the students' poor performance. This finding was supported by findings of Maimela and Monyatsi (2016), Arshad et al. (2018) and, Ayaz et al. (2017) who reported that lack of libraries and laboratories are significant factors that influence the poor performance of students. Availability of library and laboratory in schools provide a good learning environment for students in reading, understanding content and, consequently, performing better. 
Agricultural Science as a practical subject requires the tools, equipment and laboratories for the effectiveness of its teaching and learning and, therefore should be availed to the students.

Lack of out-of-school agricultural activities was identified as the third most important cause of students' poor performance Maimela and Monyatsi (2016). Out-of-school activities are learning situations or tasks in which students participate directly to gain experience. Field trips, study tours, demonstrations and experiments are some important out-of-school activities and resources are of great value for students as they prompt students to be active seekers of knowledge (Fleming et al., 2013). An educational field trip can give Agricultural Science students an opportunity to meaningfully learn and construct knowledge that improves their performance in the subject. Such trips can be organised to the well-established public and private commercial farms, agricultural research institutions, zoos, game reserves, agro-industries and other institutions related to agriculture (Ogbuluijah, 2014). Poor teaching methods are also reported as significant causes of students' poor performance (Modebelu \& Nwakpadolu, 2013).

Gegbe and Koroma (2014) reported that poor teaching methods contribute to the poor performance of students, while Ojukwu (2015) and Moyo and Maseko (2016) stated that poor teaching methods and failure to use instructional material effectively also influence the performance of students. Although teachers are encouraged to facilitate active participation in the class, the learner-centred methods should be used to suit the students' abilities (McLead, 2018). Poor teaching methods are also related to the shortage of tools and equipment, lack of libraries and laboratories, lack of out-of-school activities and lack of time to complete the syllabus and should thus be improved upon in order to enhance effective teaching methods. Lack of agriculture-related practical work came as the fifth important cause for the poor performance of students. This finding supports the one by Lee and Sulaiman (2018) who report that students who are involved in practical agricultural work performed better than those who were not. Further, Ojukwu (2015) and, Moyo and Maseko (2016) determined that the inadequacy of practical experience influenced the performance of students negatively. With agricultural education being a practical subject, it is expected that each student should have a small plot on which to learn about gardening and practical farming (Talathi et al., 2014).

This study identified the six most important suggestions to improve academic performance as including more practical work in the syllabus, ensuring tutoring/help out of class, increasing practical work, providing accessible internet, providing updated textbooks and activating agricultural clubs. The suggestion to include more practical work in the syllabus is a reflection of the existing imbalance between practical and theoretical content in the syllabus as the theoretical content dominates the practical component (Oitsile, \& Oats, 2020). Increasing the practical content may expose students to the real life experiences in learning agriculture as a subject and may generate student interest in learning agriculture. Tutoring is another strategy suggested for improving students' 
achievement (Mphale \& Mhlauli, 2014). Some slow learners may need extra help in order to understand the content, which requires extra time and attention. The need to ensure tutoring or help out of class is in recognition of the fact that learning is an individual process and differs from learner to learner.Private tutoring can have positive impact on students' performance (Berberoğlu \& Tansel, 2014).

Increasing practical work in order to improve students' achievement requires the facilities such as farm land, equipment and laboratories. In Botswana, some primary schools do not have garden tools and implements while others do not have adequate land for demonstrations and to accommodate all the learners. Tapiwa (2021), Darko et al. (2016a) and Waithira (2013) explained that practical teaching of agriculture in high schools was greatly hampered by lack of school gardens, educational trips, demonstration plots and well-equipped laboratories. All of these inadequacies hinder practical training and force theoretical teaching which restricts hands-on skills development. Practical training in agriculture is rooted in the constructivist perspective that children learn by doing rather than by being told. Thus, the lack of out-of-school activities and practical work in agriculture pose a serious challenge to the learning situations ought to be realitybased to enable students to develop and practise the skills on their own. In the current situation of covid pandemic it becomes more relevant as shifting face to face teaching of agriculture completely to online mode may not be possible and need to device a hybrid mode whereby students can be exposed to some out of class activities (Muthuprasad et al., 2021).

In the era of Information and Computer Technology (ICT), accessible internet is a way to improve student performance. Islam et al., (2018) reported that access to internet improves academic performance. Excessive internet use can lead to abnormal behaviour (Kumar et al., 2019) leading to negative influence on students' academic achievement and should, therefore, be regulated effectively (Feng et al., 2019). Updating textbooks can also improve academic performance of students. As noted by Fernandez (2014), the availability of textbooks appears to be the most important factor in improving teacher effectiveness. Mupa and Chinooneka (2019) reported a high correlation between availability of textbooks and achievement. Thus, a school that lacks adequate textbooks and revision books is likely to have a poor performance on the part of teachers and students. Agricultural club provides a platform for acquisition and application of agricultural skills through active learning/learning by doing. Such clubs significantly improve higher learning skills and achievements than a normal classroom (Saduak et al., 2019). As agriculture is based on active learning, agricultural clubs should be an essential part of the daily school life as it promotes the acquisition of knowledge and skills among the students. Therefore, it becomes crucial to establish new or activate the existing agricultural clubs in schools.

\section{Conclusion}

This study assessed the causes of primary school students' poor performance and explored possible ways to improve students' performance in agriculture in primary schools in Botswana. Twenty-five causes of poor performance of 
students in agriculture were identified and the six most important ones were identified as the shortage of tools and equipment, lack of libraries and laboratories, lack of out of schools agricultural activities, poor teaching methods, lack of practical work and, students' negative attitude towards learning. The study also identified twenty-five ways to improve the performance of students. The six most important ways are a more practical work in the syllabus, ensuring the tutoring/help out of class, increasing the practical work, providing accessible internet, providing updated textbooks and activating agricultural clubs. Female students and students studying in urban schools consider these causes more important than others as compared to their male counterparts. The eleven causes of poor performance which showed a significant difference in performance between male and female students were determined. These causes were the shortage of tools and equipment, students' negative attitude towards learning, poorly committed students, lack of active agricultural clubs, too much practical work, less time to complete the syllabus, outdated textbooks, too much theoretical work, lack of proper school gardens and improper methods of assessment. The eleven causes showed significant difference in the performance between the students in schools located in rural and urban areas. These causes include lack of libraries and laboratories, lack of practical agricultural work, teachers' negative attitude towards teaching, lack of internet in schools, poor examination structure, lack of tutors help outside the classroom, poor parental involvement, lack of homework, outdated textbooks, lack of proper school gardens and poor curriculum/syllabus.

\section{Recommendations}

In order to improve the primary school students' performance in agriculture, it is recommended that policy makers and administrators should include more practical component in the syllabus, ensure out-of-class help for students, increase practical class work, provide access to the internet, provide updated textbooks and activate agricultural clubs in the schools. Further studies are recommended to determine the reasons for the differences in the causes of poor performance of students in agriculture between male and female students, and students studying in rural and urban schools in Botswana.

\section{Limitations}

This study has a limitation as it only involves the respondents from four primary schools in Botswana. Thus, the findings may not be generalized to the country as a whole. This limitation can be addressed by conducting research studies with a more representative number of schools and students in Botswana.

\section{References}

Arshad, M., Qamar, Z. A., \& Gulzar, F. H. (2018). Effects of physical facilities at public schools on students' achievement in Punjab, Pakistan. Global Social Sciences Review, 3(4), 102-113. http:/ / dx.doi.org/10.31703/gssr.2018(III-IV).02

Asamoah, D. (2018). Perceived causes of low academic performance of Senior high school students in core mathematics in the Kumasi metropolis (Doctoral dissertation, University of Cape coast).

Ayaz, M., Ali, N., Khan, A. B., Ullah, R. \& Ullah, M. (2017). Impact of school library on students' academic achievement at Secondary School Level in Southern Districts 
of Khyber Pakhtunkhwa. International Journal of Academic Research in Business and Social Sciences, 7(5), 95-103. https://doi.org/10.6007/IJARBSS/v7-i5/2880

Baliyan, S. P., \& Nenty, H. J. (2015a). Demographic factors influencing senior secondary school students' attitude towards agriculture in Botswana. International Journal of Education and Research, 3(10), 457-470.

Baliyan, S. P., \& Nenty, H. J. (2015b). Factors underlying attitude towards agriculture as a predictors of willingness to enrol in the subject by secondary school students in Botswana. Journal of Educational and Social Research, 5(1), 377-386.

Bayat, A., Louw, W., \& Rena, R. (2014). The impact of socio-economic factors on the performance of selected high school learners in the Western Cape Province, South Africa. Journal of Human Ecology, 45(3), 183-196. https:// doi.org/10.1080/09709274.2014.11906692

Berberoğlu, G., \& Tansel, A. (2014). Does private tutoring increase students' academic performance? Evidence from Turkey. International Review of Education, 60(5), 683701. https://doi.org/10.1007/s11159-014-9436-y

Bizimana, D., \& Orodho, J. A. (2014). Teaching and learning resource availability and teachers' effective classroom management and content delivery in secondary schools in Huye District, Rwanda. Journal of Education and Practice, 5(9), 111-122.

Boipono, M., \& Margret, K. (2014). Change of assessment structure and performance: The case of PSLE Agriculture in Botswana. International Journal of Research in Humanities, Arts and Literature, 2(4), 189-194.

Botswana Examination Council [BEC]. (2015, 2018, 2019). Primary School leaving examination summary Results. http://www.bec.co.bw/test-data/2011-psle summary.pdf/view

Bulala, T., Ramatlala, M., \& Nenty, H. J. (2014). Location as a factor in the prediction of performance in Botswana Junior School Certificate Agriculture Examination by Continuous Assessment Scores. Journal of Scientific Research, 5(1), 11-14. http://dx.doi.org/10.4236/ce.2014.51004

Bush, T., Joubert, R., Kiggundu, E., \& Van Rooyen, J. (2010). Managing teaching and learning in South African schools. International Journal of Educational Development, 30(2), 162-168. https://doi.org/10.1016/j.ijedudev.2009.04.008

Creswell, J. W. (2017). Research design: Qualitative, quantitative, and mixed methods approaches. Sage publications.

Darko, R. O., Yuan. S., Simmons, K., Abbey, A., Liu, J., \& Kuma, F. (2016a). Constraints encountered in teaching practical Agriculture in selected Senior High School in the Sekondi-Takaradi Metropolis. International Journal of Information Research and Review, 3(7), 2604-2611. http://hdl.handle.net/123456789/4397

Darko, R. O., Yuan, S., Opoku, S. F., Ansah, C. O., Liu, J., \& Ansah, N. (2016b). Gender differences in attitude towards the learning of agricultural science in senior high schools in the South district of the Central region, Ghana. Journal of Agricultural Science (Toronto), 8(9), 143-151. http://dx.doi.org/10.5539/jas.v8n9p143

David, N. M. (2014). Determinants of poor academic performance of secondary school students in Sumbawanga district, Tanzania [Doctoral dissertation, Sokoine University of Agriculture].

Davis, R. J., \& Jayaratne, K. S. U. (2015). In-Service training needs of Agriculture teachers for preparing them to be effective in the $21^{\text {st }}$ Century. Journal of Agricultural Education, 56(4), 47-58. https://doi.org/10.5032/jae.2015.04047

Department of Economics and the Bureau for Economic Research at the University of Stellenbosch.

http://www.ekon.sun.ac.za/wpapers/2012/wp132012/wp132012.pdf 
Ezeudu, S. A., Gbendu, G. O., \& Joshua, E. U. (2014). School location versus academic achievement in Geography: Does reflective inquiry instructional technique has effect. Indian Journal of Research, 3(9), 209-216.

Feng, S., Wong, Y. K., Wong, L. Y., \& Hossain, L. (2019). The Internet and Facebook usage on academic distraction of college students. Computers \& Education, 134, 41-49. https:// doi.org/10.1016/j.compedu.2019.02.005

Fleming, R. W., Wiebel, C., \& Gegenfurtner, K. (2013). Perceptual qualities and material classes. Journal of Vision, 13(8), 9-19. https:// doi.org/10.1167/13.8.9

Gegbe, B., \& Koroma, J. M. (2014). Students and teachers' perception of the causes of poor academic performance in general and further mathematics in Sierra Leone: A case study of Bo District Southern Province. International Journal of Engineering Research and General Science, 2(5), 240-253. https://doi.org/10.1167/13.8.9

Hurst, S. D., Roberts, T. G., \& Harder, A. (2015). Beliefs and attitudes of secondary agriculture teachers about global agriculture issues. Journal of Agricultural Education, 56(1), 188-202. https://doi.org/10.5032/jae.2015.01188

Islam, S., Malik, M. I., Hussain, S., Thursamy, R., Shujahat, M., \& Sajjad, M. (2018). Motives of excessive Internet use and its impact on the academic performance of business students in Pakistan. Journal of Substance Use,23(1), 103-111. https:// doi.org/10.1080/14659891.2017.1358305

Jaiswal, P. (2019). Using constructive alignment to foster teaching learning processes. English Language Teaching, 12(6), 10-23. https://doi.org/10.5539/elt.v12n6p10

Jato, M., Ogunniyi, S. O. \& Olubiyo, P. O. (2014). Study habits, use of school libraries and students' academic performance in selected secondary schools in Ondo West Local Government Area of Ondo State. International Journal of Library and Information Science, 21(1), 56-72. https:// doi.org/10.5897/IJLIS2012.0412

Kabote, S. J., Niboye, E. P., \& Nombo, C. I. (2014). Performance in mathematics and science subjects: a gender perspective for selected primary schools in rural and urban Tanzania. International Journal of Gender Studies and Women's Studies, 5(3), 87-105. http://dx.doi.org/10.15640/ijgws.v2n3a6

Kumar, N., Kumar, A., Mahto, S. K., Kandpal, M., Deshpande, S. N., \& Tanwar, P. (2019). Prevalence of excessive Internet use and its correlation with associated psychopathology in 11th and 12th grade students. General Psychiatry, 32(2), 1-8. https://doi.org/10.1136/gpsych-2018-100001

Lee, M., \& Sulaiman, F. (2018). The effectiveness of practical work in Physics to improve students' academic performances. PEOPLE: International Journal of Social Sciences, 3(3), 1404-1419. https://dx.doi.org/10.20319/pijss.2018.33.14041419

Macatta, M. (2016). Importance of agricultural sector in a county's economic development. http://www.ippmedia.com/en/features/importanceagricultural-sector-country's-economic-development.htm

Mahmood, T., \& Gondal, M. B. (2017). Effect of school environment on student's achievement: Cross comparison of Urdu and English medium classes in Punjab province. Pakistan Journal of Education, 34(1), 67-80.

Maimela, M., \& Monyatsi, P. P. (2016). Factors that influence the performance of students in Botswana. IOSR Journal of Humanities and Social Science, 21(9), 40-53.

McLead, S. A. (2018, Aug 05). Lev Vygotsky. http://www.simplypsychology.org/veygotsky.html.

Modebelu, M. N., \& Nwakpadolu, G. M. (2013). Effective teaching and learning of Agricultural Science for food security and national sustainability. Journal of Educational and Social Research, 3(4), 161-170. https://doi.org/10.5901/jesr.2013.v3n4p161 
Moll, H. (2020). How young children learn from others. Journal of Philosophy of Education, 54(2), 340-355. https:// doi.org/10.1111/1467-9752.12417

Moyo, W., \& Maseko, T. (2016). Factors influencing poor performance of learners in the grade seven examinations: A Case of Umguza District. International Journal of Academic Research in Business and Social Sciences, 6(1), 236-243. https://econpapers.repec.org/RePEc:hur:ijarbs:v:6:y:2016:i:1:p:236-243

Mphale, L. M. \& Mhlauli, M. B. (2014). An investigation on students' academic performance for Junior Secondary Schools in Botswana. European Journal of Educational Research, 3(3), 111-127. https://doi.org/10.12973/eu-jer.3.3.111

Muchena, P. K. (2013). Factors influencing students' enrolment in agriculture subject in public secondary schools in Kiambu East District, Kiambu County, Kenya [M.Ed thesis, University of Nairobi, Kenya]

Mupa, P., \& Chinooneka, T. I. (2019). Factors contributing to ineffective teaching and learning in Primary Schools: Why are schools in decadence? Journal of Education E Practice, 6(19), 125- 132. https://files.eric.ed.gov/fulltext/EJ1079543.pdf

Muthuprasad, T., Aiswarya, S., Aditya, K. S., \& Jha, G. K. (2021). Students' perception and preference for online education in India during COVID-19 pandemic. Social Sciences $\&$ Humanities Open, 3(1), 100-101. https://doi.org/10.1016/j.ssaho.2020.100101

Mutua, J., \& Oyoo, S. (2020). Gender differences in learning strategies and academic achievement among Form Three Secondary School Students in Nairobi County, Kenya. International Journal of Applied Psychology, 10(1), 1-7. http://kerd.ku.ac.ke/123456789/327

Nsa, S. O., Offiong, A. A., Udo, M. F., \& Ikot, A. S. (2014). School environmental variable and students' academic performance in Agricultural Science. International Journal of Business and Social Science, 5(1), 163-167.

Ogbuluijah, J. N. (2014). The Impact of student's field trips on academic performance in Agricultural Science in selected secondary schools in Rivers State. Research on Humanities and Social Sciences, 4(17), 118-128.

Ogweno, O. P. (2015). Teaching and learning resources as determinants of students academic performance in Secondary Agriculture, in Rachuonyo North Sub Country, Kenya. International Journal of Advance Research, 3(9), 577-587. http://repository.rongovarsity.ac.ke/bitstream/handle/123456789/2131/Peter \%20Oyier\%20Ogweno\%20634_IJAR-7034.pdf?sequence=1\&isAllowed=y

Oitsile, N., \& Oats, R. A. (2020). Comparative study on the performance of students in PSLE and JCE agriculture. Lonaka JoLT, 11(2), 80-90.

Ojukwu, M. O. (2015). Perception of students on causes of poor performance in Chemistry in External Examinations in Umuahia North Local Government of Abi State. International Journal of Education and Literacy Studies, 4(1), 67-73. http://dx.doi.org/10.7575/aiac.ijels.v.4n.1p.67

Osaikhiuwu, O. C. (2014). Institutional factors affecting the academic performance of public administration students in a Nigerian University. Public Administration Research, 3(2), 171-177. http://dx.doi.org/10.5539/par.v3n2p171

Osman, A., Owino, O. A., Yungungu, A. M., \& Ogolla, B. O. (2015). The relationship between availability of teaching/learning resources and performance in KCSE Biology in selected Secondary Schools in Nyakach Sub-County, Kisumu County, Kenya. International Journal of Contemporary Applied Science, 2(7), 153-168.

Otekunrin, O. A., Otekunrin, O. A., \& Oni, L. O. (2019). Attitude and academic success in Practical Agriculture: Evidence from Public Single-Sex High School students in Ibadan, Nigeria, Asian Journal of Advanced Research and Reports, 4(3), 1-18. 
Rahmawati, K., \& Ummah, S. S. (2020). The Comparison between male and female students in Reading Comprehension Achievement at the third semester of TBI STAIN Pamekasan. PANYONARA: Journal of English Education, 2(1), 69-79.

Saduak, W., Poungsul, P., \& Phonpakdee, R. (2019). School Agricultural Learning Center for sustainable agricultural learning. Journal for the Education of Gifted Young Scientists, 7(3), 389-407. http://dx.doi.org/10.17478/jegys.582993

Saunders, M., Lewis, P., \& Thornhill, A. (2016). Research methods for business students. $7^{\text {th }}$ ed. Pearson.

Shuell, T. (2016). Theories of learning. http://www.education.com/reference/article/theories-of-learning/

Sibanda, C., Hulela, K. \& Tselaesele, N. (2016). Perceived influencers of the decline on performance of students in Botswana General Certificate of Secondary Education's Agriculture Examination Results. Journal of Education and Learning, 5(1), 100-209. http://dx.doi.org/10.5539/jel.v5n1p199

Solly, M., \& Koloi-Keaikitse, S. (2019). Practical performance as a predictor of theory in Botswana Junior Certificate Agriculture, Mosenodi Journal, 22(2), 89-101.

Spaull, N. (2012). Poverty and Privilege: Primary School Inequality in South Africa. Stellenbosch Economic Working Papers: 13/12: A Working Paper of the

Taber, K. S. (2018). The use of Cronbach's alpha when developing and reporting research instruments in science education. Research in Science Education, 48(6), 1273-1296. https://doi.org/10.1007/s11165-016-9602-2

Talathi, S., Naik, M. \& Jalgaonkar, R. (2014). Introduction to the agriculture and agronomy. Bombay: Bombay Press Limited.

Tapiwa, K. A. (2021). Assessing challenges faced in the teaching and learning of practical Agriculture using practical projects at Ordinary level: A case of Masvingo South. International Research Journal for Quality in Education, 8(1), 11-14.

Thoron, A. C., \& Myers, B. E. (2010). Perceptions of pre-service teachers toward integrating science into school-based agricultural education curriculum. Journal of Agricultural Education, 51(2), 70-80. https:// doi.org/10. 5032/jae.2010.02070

Waithira, K. S. (2013). Challenges to Teaching and Learning of Agriculture in Secondary Schools in Kakuyini Division, Kangundo District, Machakos County [M.Ed Thesis, Kenyatta University]. 